\title{
When the virus goes viral: An impetus to revisit COVID-19 scientific outrage using Web of Science platform and a recount on the lineage of pandemics
}

\author{
Shareefraza Ukkund ${ }^{1}$, Bhavna Alke ${ }^{2}$, Momin Ashraf ${ }^{3}$, Aliya F. Badiuddin ${ }^{1}$, Shweta \\ Varute $^{1}$, Mayur K. Nakum ${ }^{1}$, Sanjana Jacob ${ }^{1}$, Anusha B. Shettar ${ }^{1}$, Ravika Patil ${ }^{4}$, Jnathri \\ Halemane $^{1}$, Meghana Kuchanur ${ }^{1}$, Chaithanya P. Kunjiveedu ${ }^{5}$, Kirankumar \\ Krishnamurthy ${ }^{5}$, and Usman T. Syed ${ }^{2}$ \\ ${ }^{1}$ Srinivas Institute of Technology \\ ${ }^{2}$ Universidade Nova de Lisboa Faculdade de Ciencias e Tecnologia \\ ${ }^{3}$ University of Strasbourg \\ ${ }^{4}$ Indian Institute of Science \\ ${ }^{5}$ Kyoto University Graduate School of Energy Science
}

April 30, 2021

\begin{abstract}
Pandemics are epidemics or disease outbreaks, which rampage across countries and continents. The ongoing corona virus disease 2019 (COVID-19) has been a full-fledged pandemic for over a year now. With the death count mounting above two million, COVID-19 has globally impacted the economy, society, public health and all spheres of human life. COVID-19 is the third type of coronavirus disease outbreak after Severe Acute Respiratory Syndrome and Middle East Respiratory Syndrome. This review paper discusses the medical perspectives of COVID-19 along with a recount on the numerous pandemics that have wreaked havoc in the past. AIDS which is ongoing, and cholera, influenza and plague have been recurring pandemics and merciless killers. Even with tremendous advancement in medical science, new pathogens continue to cause uncontrollable infections and deaths worldwide. Research in the fields of medicine, health and social sciences, psychology and so on is soaring as the world battles with COVID-19. Additionally, scientometric analysis has been performed using the Web of Science platform, a global citation database, to project the impact of COVID-19 on research in terms of scientific publications. As of 04th April 2021, 98,020 scientific works have been published of which $28 \%$ are from the USA. Medical and health sciences have been the major focus of research globally, as the world works tirelessly to develop the 'right' vaccine that will make COVID-19 a disease of the distant past.
\end{abstract}

\section{Hosted file}

Manuscript_Blinded.pdf available at https://authorea.com/users/411005/articles/520193-whenthe-virus-goes-viral-an-impetus-to-revisit-covid-19-scientific-outrage-using-web-ofscience-platform-and-a-recount-on-the-lineage-of-pandemics 
<smiles>C=CC=C</smiles> 


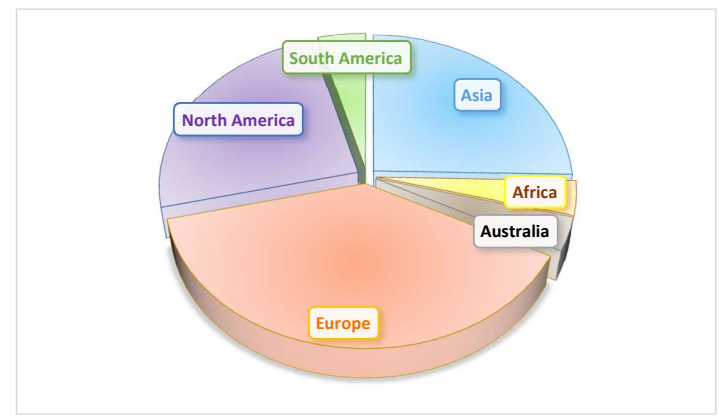

\begin{tabular}{|c|c|c|c|c|c|c|c|}
\hline \multirow[t]{2}{*}{$\begin{array}{l}13,738 \\
\text { GENERAL INTERNAL MEDICI }\end{array}$} & 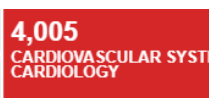 & $\begin{array}{l}3,514 \\
\text { sURGERY }\end{array}$ & \multirow[t]{2}{*}{ 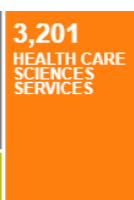 } & \multirow{2}{*}{\multicolumn{2}{|c|}{ 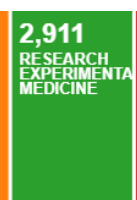 }} & \multirow[t]{2}{*}{\begin{tabular}{|l|} 
2,824 \\
PSYCHOLOG
\end{tabular}} & \multirow[t]{2}{*}{$\begin{array}{l}2,787 \\
\text { ONCOLOGY }\end{array}$} \\
\hline & \multirow{2}{*}{$\begin{array}{l}\mathbf{3 , 8 2 2} \\
\text { SCIENCEIIECHNOLOGY } \\
\text { OHHER TOPCS }\end{array}$} & \multirow{2}{*}{$\begin{array}{l}3,353 \\
\text { EXIRONMENAL } \\
\text { SCIECECSECOLOGY }\end{array}$} & & & & & \\
\hline \multirow{4}{*}{$\begin{array}{l}\mathbf{8 , 3 4 0} \\
\text { PUBUCENURONMENAL } \\
\text { OCCUPAIONAL HEALIHA }\end{array}$} & & & \multirow{2}{*}{\multicolumn{2}{|c|}{$\begin{array}{l}2,626 \\
\text { BUSINESS }\end{array}$}} & \multirow{3}{*}{ 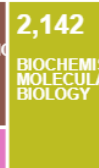 } & \multirow{3}{*}{ 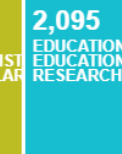 } & $\begin{array}{l}2,031 \\
\text { mсRовіо }\end{array}$ \\
\hline & \multirow{3}{*}{$\begin{array}{l}\mathbf{3 , 7 3 2} \\
\text { NEUYOSOLIENCES } \\
\text { NEUROLOGY }\end{array}$} & \multirow{3}{*}{$\begin{array}{l}3,328 \\
\text { PSYCHATRY }\end{array}$} & & & & & \\
\hline & & & 2,353 & & & & \\
\hline & & & & \multirow{2}{*}{\multicolumn{3}{|c|}{ 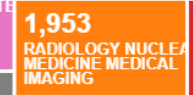 }} & \multirow{3}{*}{ 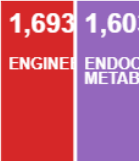 } \\
\hline \multirow{2}{*}{$\begin{array}{l}\mathbf{4 , 6 6 8} \\
\text { INFECCIOUS DISEASES }\end{array}$} & \multirow{2}{*}{\begin{tabular}{|l|}
3,697 \\
PHARMACOLOGY PHARM
\end{tabular}} & \multirow{2}{*}{$\begin{array}{l}\text { 3,311 } \\
\text { mmunoLogr }\end{array}$} & & & & & \\
\hline & & & |, PEDIATIRICS & \multicolumn{3}{|c|}{$\begin{array}{l}1,775 \\
\text { HEMATOLOGY }\end{array}$} & \\
\hline
\end{tabular}

